\title{
Do we follow the money? The drivers of migration across regions in the EU
}

\author{
Andrés Rodríguez-Pose ${ }^{1}$, Tobias Ketterer ${ }^{2}$, David Castells-Quintana ${ }^{3}$ \\ ${ }^{1}$ London School of Economics, London, UK (email: a.rodriguez-pose@lse.ac.uk) \\ ${ }^{2}$ Directorate-General for Economic and Financial Affairs, European Commission* \\ (email: tobias.ketterer@ec.europa.eu) \\ ${ }^{3}$ Universidad Autònoma de Barcelona, Barcelona, Spain; Universidad de Barcelona, Barcelona, Spain \\ (email: dcastells@ub.edu)
}

Received: 10 June 2014/Accepted: 10 November 2015

\begin{abstract}
Most immigration theories tend to highlight that migration follows wealth and economic dynamism, but is this also the case across regions in Europe? The aim of the paper is to investigate whether migrants in Europe indeed follow the money, and to contrast this with a variety of potential alternative explanations, including the presence of migrants from a similar origin. The analysis is based on panel data estimations including 133 European regions over a time period of 17 years. Different lag structures have been employed in order to distinguish between short- and longrun effects. The results cast some doubt about the prominence of pecuniary factors as determinants of cross-regional migration in Europe, with little evidence to support the idea that migration follows economic dynamism. Network effects, human capital related-, and territorially embedded innovation enhancing regional characteristics, by contrast, seem to play a much stronger role than hitherto considered.
\end{abstract}

Key words: Inter-regional migration, mobility, regional economic growth, social networks, regions, Europe

\section{Introduction}

How important are pecuniary incentives for migration? According to most migration theories, they are crucial. Early theories relied heavily on regional differences in income and living standards as the main motivation for migration, in general, and for rural-tourban migration, in particular (Hicks 1932, Harris, Todaro 1970). Since then, money and jobs have remained the magnets for migrants in migration theory (e.g. Fields 1979, Lundborg 1991, Schmidt et al. 1994). Most traditional empirical studies on migration have thus tended to focus on differences in living standards and economic dynamism as the key factors behind geographical mobility (Greenwood 1997, Puhani 2001).

Interregional migration patterns within Europe in the last decades however, fly in the face of these theories. Despite substantial and persistent regional disparities in wealth, unemployment rates and economic performance (Puga 2002) - notwithstanding freedom of mobility across much of the EU - migration rates within the EU have remained

\footnotetext{
*This paper reflects the views of the author only and should not be attributed to the European Commission.
} 
relatively subdued (Décressin, Fatàs 1995, Fatàs 2000). According to (Huber 2004, 619), "it takes several years or decades before regional unemployment disparities are evened by migration." So, if differences in wealth, wages, and employment levels are critical for migration, why has interregional mobility in the EU remained low for so long? Do migrants really follow the money as predicted by traditional theory? Or are there other factors that significantly influence migration at the regional level? In particular, are there potential roles for social networks and other place-based regional externalities as important determinants of migration decisions at the European regional level?

This paper aims to address these questions. Using migration data for 133 European regions during the period in-between 1990-2006, we examine the relevance of pecuniary factors in determining migration trends, by estimating dynamic panel data models. The objective is to first determine the relevance of pecuniary motivations and secondly, to evaluate whether regional wealth, economic dynamism, and job availability are more important than the presence of other migrants, social networks, or other additional regional characteristics, in shaping migration flows across Europe's regions.

In order to achieve this aim, the paper first briefly reviews the theoretical literature on the relationship between pecuniary rewards and migration, before contrasting the potential strength of this relationship with that of other possible migration drivers (Section 2). Section 3 presents a discussion of the data, introduces the variables used in the model and finally provides the empirical specification and justification of the econometric approach. The empirical results are presented and interpreted in Section 4. Section 5 concludes that EU cross-regional migration in recent years is to a greater extent the result of past migration trends, human capital related and territorially-embedded externalities, than simply the differences in wealth across territories.

\section{Theoretical considerations: money and other migration drivers}

Since the early work of Hicks (1932), financial rewards to individual mobility have been regarded as the fundamental magnet for migrants. According to Hicks $(1932,76)$, "differences in net economic advantages, chiefly differences in wages, are the main causes of migration." Migrants would regard differences in wages and expected incomes across territories as an opportunity to improve personal wealth, welfare, and living standards (Sjaastad 1962). According to these theories, migrants move in expectation of a higher utility in their destination (Sjaastad 1962, Greenwood 1997), making differences in wages or other forms of incomes across territories the driving force of regional migration. Consequently, the higher the differential of region-specific earning opportunities and the higher the probability of finding a job in the region of destination, the higher the migration flows between home- and host-territory (Harris, Todaro 1970).

The source of unequal earning opportunities across regions has traditionally been rooted in differences in input factor endowment levels (Ranis, Fei 1961, Öberg 1997). In this neoclassical framework, geographical differences in demand and supply of labour trigger migration. Territories with abundant labour supply relative to capital have low marginal returns on labour, whereas territories with relative scarce labour endowments are characterized by higher labour returns. The resulting differences in marginal products lead to different wage levels across territories and are therefore considered the main stimulus behind labour mobility. Under conditions of perfect competition, perfect labourand capital mobility, classical migration theory predicts people to move from low- to high- labour-productivity regions, leading to an increase of migrants' utility due to higher expected net income levels in high-productivity areas (Borjas 1989, Bauer, Zimmermann 1997, Öberg 1997). ${ }^{2}$

However, when assessing the potential maximization of their lifetime earnings, wouldbe-migrants have also been found to weight their future career benefits against the financial and psychological costs of leaving their place of origin (Lee 1972, Tassinopoulos,

\footnotetext{
${ }^{2}$ Further assumptions of the neoclassical model are full employment, homogenous supply of labour, perfect information and transparency, and the absence of transportation costs (Sjaastad 1962). Moreover, traditional migration theories also predict wage convergence between host and source regions, which result in an equalization of real wages across all regions (Todaro 1969).
} 
Kristensen 1998). This cost-benefit calculation involves aspects of investments in human capital. Given certain skill-related attributes, potential migrants choose to move to areas where they believe they can be most productive. Nevertheless, before reaping the expected benefits - mostly in the form of higher wages - migrants have to make certain efforts. These efforts may include learning a new culture and language, the costs of adapting to new working systems, the psychological costs of leaving old social ties behind and forging new ones, but also a number of material costs in the form of travelling and maintenance costs when looking for a new job (Massey et al. 1993). Theory predicts that potential migrants are likely to factor in possible short- or medium-term losses, due to a lack of complete information, or due to the assimilation into a new environment and labour market, in expectation of greater returns in the future (Borjas et al. 1992). When considering moving would-be migrants will estimate the benefits of earnings and employment opportunities in both the home and the potential destination markets, "deduct the costs of making the move, and choose whichever option maximises the net present value of lifetime earnings" (Tassinopoulos, Kristensen 1998, 8). This implies that regions offering the highest pecuniary and financial returns on migration remain to be more attractive for potential migrants (Lee 1972, Pekkala 2002, 2003). Traditional migration theory thus "typically leads to the conclusion that people migrate [...] from regions experiencing a downward economic trend to regions experiencing an economic expansion" (Hooghe et al. 2008, 478). These views have frequently been corroborated by empirical studies. By linking expected future earnings to economic dynamism, Haapanen (2000) for instance, shows that internal migrants in Finland are more like to move to economically prospering regions, and that the elasticity of migration propensity for dynamic regions is over twice as large as that of peripheral regions.

Wage-based migration motives are complemented by financial incentives based on other forms of income, such as state transfers or other public amenities. High re-distributional transfers, on one hand may provide an insurance against the risk of income losses (e.g., due to unemployment) and on the other, increase the overall availability of public goods. Both aspects will increase the utility of (risk-averse) individuals. The consequences on aggregated migration flows are twofold. Whilst potential migrants may be attracted by higher social welfare spending in the host territories, individuals already benefiting from relatively high public social spending may be less willing to leave their places of origin (Haapanen, Ritsilä 2007). Day (1992) for example, shows that inter-provincial migration flows in Canada are significantly influenced by provincial government expenditure policies regarding unemployment insurance benefits and direct transfer payments to individuals. The magnitude and variability of future lifetime earnings is however also subject to a certain degree of uncertainty regarding institutional aspects in the new host area (Ghatak et al. 1996). Informational asymmetries regarding the disposability of public goods, health care, schooling, or the quality of life, as well as uncertainties about employment opportunities and unobservable wages in more advanced regions, may prevent people from leaving economically less attractive regions. Informational asymmetries may also be strongly conditioned by distance (Greenwood 1975, 1997, Zimmermann 2005); the larger the distance between home and host area, the greater the risks and costs of movement. Conversely, information about labour market conditions and social amenities is expected to increase the closer the potential destination is (Zimmermann 2005).

Motives to migrate by an individual are further influenced by a number of other factors. The probability for example, of finding a job in the host region plays a crucial role. High unemployment rates, as well as high ratios of long-term unemployment, may both discourage migration in-flows and simultaneously act as an important 'push-factor' for potential migrants (Todaro 1969, Pissarides, McMaster 1990). Migration therefore, can be considered an intrinsic part of the search process for jobs (Décressin 1994, Huber 2004). The likelihood of migrating and finding a job are highly conditioned by the level of education of the individual (Fields 1975, Zimmermann 2005). Regions possessing industries employing predominantly highly educated people should thus, attract more migrants relative to regions with prevailingly low-skilled labour. Burda, Wyplosz (1992) for instance, show, in the context of East-West European migration, that the most likely movers are the young and the highly educated. Rodríguez-Pose, Vilalta-Bufí (2005, 559) 
also find that economically more dynamic regions and "those with a stronger foothold in the knowledge economy" tend to have the greatest capacity to attract highly educated people. As a result, the decision to migrate seems to be affected by a combination of individual and regional characteristics stretching beyond the usual scope of traditional economic migration drivers.

Place-based regional conditions are other factors behind migration, which are attracting increasing interest. Favourable socio-economic features for example, are likely to allow migrants a fast transition into jobs that best suit their abilities, as well as accelerate assimilation in a new structural and administrative system. Favourable human capital endowments and high regional development levels also increase the probability of individuals boosting their own productivity and wages through interaction with others in the region (Rudd 2000, Rodríguez-Pose, Tselios 2012). Individuals moving to highly skilled and well-off regions will therefore benefit from knowledge-spillovers. The presence of large groups of poor and educationally disadvantaged individuals in a region by contrast, will lower overall productivity and thus the region's attractiveness towards potential migrants (Di Addario, Patacchini 2008). Other socio-economic features shaping regional migration flows relate to the structure and the demographic composition of the population. Age has a significant influence on migration decisions (Massey et al. 1993, Tassinopoulos, Kristensen 1998). The propensity to migrate considerably decreases with age (Zimmermann 2005). Hence, regions with a relatively young population structure will have a higher out-flow of (young) people. In addition, tight conditions on local labour markets - especially for young people - could enhance migration (Cairns, Menz 2007).

More recently, urban and natural amenities, as well as aspects related to the quality of life have been prominent features of migration analyses (e.g. Florida 2002, Ferguson et al. 2007, Partridge 2010, Rodríguez-Pose, Ketterer 2012). The beauty and accessibility of the natural environment or the vibrancy of a region's cultural life has been highlighted as potentially a key component in the attraction of talent and skills (Partridge 2010), although this role may be waning (Partridge et al. 2012). ${ }^{3}$

Past migration trends also play a central role in determining the appeal of any given territory for new migrants. The presence of migrants of a similar origin will not only determine the direction of migration flows, but also their persistence. Social network linkages stretching from home to host regions will considerably reduce the costs and risks of migrating for certain groups (Massey et al. 1998). The presence of groups from the same geographical origin in any given region will allow future members of those communities to gain easier access to jobs and reduce the costs of assimilation in new cultural or administrative structures (Massey et al. 1993). This may trigger path dependence, whereby current migration flows may be substantially influenced by the magnitude and direction of past migration movements, reflecting potential chain migration effects on the ethnic group, village, or even family level (Massey, Gracia 1987, Bauer, Zimmermann 1997, Shah, Menon 1999). Group, family, and household ties may also make migration a collective decision. Collective decision-making by larger units of related people, rather than by isolated individuals, may serve as a mean to pool resources and to ensure a higher overall expected income, lower risk, while contributing to loosen several (capital) constraints due to various market failures, albeit often at the expense of individual freedom of choice (Katz, Stark 1988, Stark 1991). As a result, individual earning opportunities may be affected by household externalities (Mincer 1978, Rodríguez-Pose, Tselios 2010).

Finally, structural features of the local economy may also affect specific types of skillrelated labour demand and therefore migration patterns across regions. The dual labour market theory (Piore 1979) highlights that migration is driven by a constant demand of migrant labour related to the economic structure of a geographical area. Different territorial characteristics are therefore likely to shape a region's economic structure and

\footnotetext{
${ }^{3}$ Amenities may play a lower role in the case of Europe than in the US. In a densely urbanised environment, easy access to natural beauty is confined to a more limited number of areas. Average temperatures across the continent are also less extreme than in North America and given its long history, the availability of cultural amenities are more homogenous and often directly related to city size and agglomeration. Hence, regional migration analyses considering amenities in Europe often reach contradictory results (see for instance Rodríguez-Pose, Ketterer 2012, Cheshire, Magrini 2006 ). Consequently, amenities are not included as an independent variable in our analysis.
} 
thereby its intrinsic labour demands (Massey et al. 1998). The structure and absolute size of the local economy are important elements in attracting certain types of migrants and determining the composition of migration flows. The pattern and size of regional economies are also strongly linked to aspects of market potential. Workers tend to be attracted by regions where the market potential is high and price levels are low, whereas firms tend to cluster in areas with a beneficial access to labour demand. These forces underline that migrants are likely to be attracted by economic agglomeration areas with smaller price indexes and consequently higher real wages (Ottaviano, Puga 1998). Different degrees of industry agglomeration and market potential may therefore influence consumers' and workers' decisions to move. Higher expected real wages in agglomerated areas due to competition among firms, as well as greater diversity, will enhance the pull of agglomerated regions for migrants (Surico 2003, Pekkala 2003). However, different views coexist regarding the effects of industry agglomeration on wages and on the spatial concentration of workers.

In light of the reviewed literature, we contribute in this paper to the empirical evidence on regional migration, by assessing how important net income advantages or pecuniary incentives are when contrasted to other factors leading to migration. In particular, we focus on the potential role of social networks and other place-based regional externalities, as important determinants in migration decisions at the European regional level. Thus, we aim to assess whether the dominant theories of migration, focused on pecuniary factors, are more important than alternative explanations behind migration trends across regions in the EU.

\section{Data, variables and econometric specification}

\subsection{Data and variables}

In order to test the importance of pecuniary returns in migration across the EU's regions and to contrast these findings with a number of additional factors influencing migration, we follow the work of Pissarides, McMaster (1990). This approach, which mostly addresses features of traditional migration drivers, is complemented by the use of methods introducing regional and place-based socio-economic externalities (RodríguezPose, Crescenzi 2008, Rodríguez-Pose, Tselios 2010). In order to measure migration, we introduce the net migration rate, defined as the difference between annual immigration and emigration relative to total regional population size (Puhani 2001, Crescenzi, RodríguezPose 2008) as the dependent variable. We consider total migration (considering migration from other EU regions, as well as migration from third-party regions). ${ }^{4}$ In-line with traditional migration theories we proxy pecuniary migration returns using differences in relative regional growth rates $^{5}$ (Haapanen 2000) and living standards, the latter in the form of GDP per capita levels (Puhani 2001, Jennissen 2003, Greenwood 1997). It is expected that regions with limited economic dynamism (i.e., low economic growth rates) and relatively low standards of living, or a low quality of life (Assadian 1995) will have a negative net migration rate, whereas rich and economically prospering regions will attract migrants.

Traditional migration models further highlight the importance of high unemployment rates as a push-factor for migration (Harris, Todaro 1970). The likelihood of finding a job depending on a region's job opportunities (vacancies) is proxied by the regional unemployment rate. We expect regions with low unemployment rates to experience migration in-flows, whereas high unemployment regions will have a negative net migration

\footnotetext{
${ }^{4}$ Because of the limited inter-regional migration data provided by Eurostat (especially for Greece and Spain) this analysis follows the approach used by Crescenzi, Rodríguez-Pose (2008) and Puhani (2001) in order to calculate the net migration rate. The data on net migration is calculated as the population change plus deaths minus births. "The net migration data retrieved in this way also includes external migration" (Puhani 2001, 132). Moreover, we standardize the net migration by the average regional population. "Consequently, it is impossible to distinguish between national, intra-EU and extra-EU migration flows" (Crescenzi, Rodríguez-Pose 2008, 72).

${ }^{5}$ Regional economic growth rates are standardized by the respective annual mean value of all the other regions, as migration is likely to be influenced by the level of income in the region of origin relative to the expected level of income that can be obtained somewhere else (cf. Pissarides, McMaster 1990).
} 
rate (Pissarides, McMaster 1990, Puhani 2001). Given that migration decisions are shaped by a comparison of various sources of expected earnings between the home and destination regions, we also include social welfare payments in the model (see for instance Day 1992, Haapanen, Ritsilä 2007). Because of the national character of most social welfare payments, we construct a re-distributional variable combining national and regional data. The aim is to connect social welfare payments determined on a national scale with a region's economic well-being. The resulting variable is calculated as the ratio of total annual national welfare payments over national GDP levels multiplied by regional GDP levels.

Following Rodríguez-Pose, Tselios (2010), we consider place-based regional externalities. These include the regional concentration of industries, which may influence migration flows by increasing the availability and remuneration of jobs in a region. However, regional agglomeration can also lead to intensified competition among workers (Rodríguez-Pose, Crescenzi 2008). As a result, real wages can either increase or suffer from a certain downward pressure (Ottaviano, Puga 1998). To proxy a region's degree of agglomeration we consider population density. Demographic factors and the important role of age in influencing migration decisions (Massey et al. 1993, Zimmermann 2005) are represented by the percentage of total regional population aged between 15 and 24 years. A region's share in this age group is standardised by the value for all other regions. Social migration networks are proxied by introducing the lagged dependent variable as a regressor in our model.

We construct a social filter index (Rodríguez-Pose, Crescenzi 2008, 56) in order to capture other important regional externalities, which may influence migration decisions. This composite index accounts for the territorially embedded innovation enhancing features of a region. The social filter therefore stands for "the unique combination of innovative and conservative [...] elements that favour or deter the development of successful regional innovation systems" (Rodríguez-Pose 1999, 82). Our social filter index is built upon two main pillars: regional educational attainments and the composition of regional productive resources. Regarding the former, education is believed to be one of the most important sources in determining the innovation creating capacity of a region (Lundvall 1992, Malecki 1997). We introduce regional education in the model, as the number of persons with completed tertiary education relative to both, the total population of the region, and relative to the total number of employed people in the region. For the composition of a region's productive resources, we use the percentage of the labour force employed in agriculture as an indicator of low productivity. Agricultural employment may even be an indicator of some form of hidden unemployment, as agricultural workers show very little mobility and in a European context, tend to be aged (Caselli, Coleman 2001).

As educational attainments and the structure of productive resources are believed to be highly dependent on one-another (Rodríguez-Pose, Crescenzi 2008), problems of multicollinearity arise. We therefore use principal component analysis (PCA) in order to construct our social filter index with the objective "to preserve as much as possible of the variability of the initial information" (Rodríguez-Pose, Crescenzi 2008, 57). The first principal component accounts for $44.2 \%$ of total variance, whilst the second component represents $35.6 \%$. The coefficients of education variables are, as expected, positive, while that of the share of employment in agriculture is negative.

The model is run for the EU-15 and covers the time period between 1990 and 2006 (time intervals are measured in years). ${ }^{6}$ The analysis is based on a mixture of NUTS-1 and NUTS-2 regions. NUTS-1 are used for Belgium, Germany, and the United Kingdom, while NUTS-2 for Austria, Finland, France, Greece, Italy, the Netherlands, Portugal, Spain, and Sweden. Countries without a regional structure were excluded from the analysis. ${ }^{7}$

\footnotetext{
${ }^{6}$ In part due to data availability our analysis focuses on the period before the crisis, when there was some catching-up between regions. An interesting extension of our paper would be an examination of a regional migration response to the most-recent crisis. One important impact of the crisis for instance, has been a mean increase in the levels of inequality within regions, but with wide dispersion across regions - with some of them actually experiencing decreases in inequality (see Castells-Quintana et al. 2015). Analysing the role for migration decisions of this differential impact of the crisis in terms of inequality could prove to be of high relevance.

${ }^{7}$ This was the case for Denmark, Ireland, and Luxemburg. The exclusion of these countries is caused
} 
In addition, some individual regions had also to be excluded due to inadequate data availability. ${ }^{8}$ In total, the analysis was conducted for 133 regions in 12 countries.

The majority of the data used for this analysis was obtained from the Eurostat Regio database. The variables on educational achievement in contrast, were retrieved from the Labour Force Survey Data also provided by Eurostat. In order to calculate national growth rates, data from the OECD database was used. The exact sources and definition of the variables included in the analyses are summarized in Table A.1 in the appendix. All variables report regional data, with the exception of the national growth-rate, which is used as an explicit control for national unobserved effects and thus minimise spatial autocorrelation (i.e., the missing independence of the residuals of neighbouring observations - Crescenzi, Rodríguez-Pose 2008). ${ }^{9}$

\subsection{Econometric specification}

As net migration flows seem to be a quite persistent over time, we consider a dynamic model. The model's dynamic form allows us to account for potential endogeneity concerns, and to consider the influence of past migration flows or migratory network linkages on current migration decisions. Given the relatively small number of time periods considered and the fact that the only available instruments are internal ones, we use a heteroscedasticity robust System Generalised Method of Moments (System-GMM) estimator for the dynamic model estimations (Roodman 2006). The specific estimator chosen is the ArellanoBover/Blundell-Bond panel data estimator in its one-step estimation version. We begin by considering a model in which contemporaneous values of the explanatory variables affect migration decisions. We then consider lagged explanatory variables, assuming that migration decisions are based on past values and behaviours (Greenwood 1985). In order to get a more complete picture of how different explanatory variables affect regional net migration over time, the model is consecutively estimated with different lag structures imposed on all independent variables. As a result, the dynamic model is successively estimated with a zero to five-lag structure for all explanatory variables (i.e., in six separate regressions). Regarding the specification of the used estimator, the lagged net migration rate is classified as endogenous in all regressions. ${ }^{10}$ Moreover, the first and the second lag have been chosen as (internal) instruments for the endogenous variables in all regressions. The use of more instruments with a higher number of time lags did not significantly change the results. Our dynamic model adopts the following form:

$$
\begin{aligned}
\text { Net-migration }_{i, t}= & \alpha+\beta_{1} \text { Past-migration }_{i, t+(n-1)}+\beta_{2} \text { Economic-growth }_{i t-n}+ \\
& \beta_{3} \text { unemployment }_{i t-n}+\beta_{4} \text { young-population }_{i t-n}+ \\
& \beta_{5} \text { agglomeration }_{i t-n}+\beta_{6} \text { Living-standards }_{i t-n}+ \\
& \beta_{7} \text { national-growth }_{i t-n}+\beta_{8} \text { Social-welfare }_{i t-n}+ \\
& \beta_{9} \text { Social-filter }_{i t-n}+\epsilon_{i t}
\end{aligned}
$$

where all variables are as described in Table A.1 in the appendix; $\alpha$ is a constant, $i$ is the regional index, $i \in[1 ; 133], t$ is the temporal index, $t \in[1990 ; 2006]$, and $\epsilon$ is the idiosyncratic error term.

\footnotetext{
by introducing the national growth-rate in order to control for national effects.

${ }^{8}$ The regions excluded due to missing data are: Ceuta and Melilla, Canary Islands, all French overseas departments (Guadaloupe, Martinique, Guyane, Réunion), Länsi-Suomi, Trento, Açores, and Madeira.

${ }^{9} \mathrm{By}$ introducing the national growth-rate as a control variable the effect of spatial autocorrelation is minimized (Rodríguez-Pose, Crescenzi 2008, 72). National growth rates are included as the ratios of GDP (PPS) volume changes between the current and the previous year over the GDP (PPS) level of the previous year.

${ }^{10}$ In the first dynamic model regression (no lags) both the lagged net migration rate, as well as the regional growth rate, have been classified as endogenous variables. National growth rates of the country to which a particular region belongs were introduced to minimize problems of spatial autocorrelation.
} 


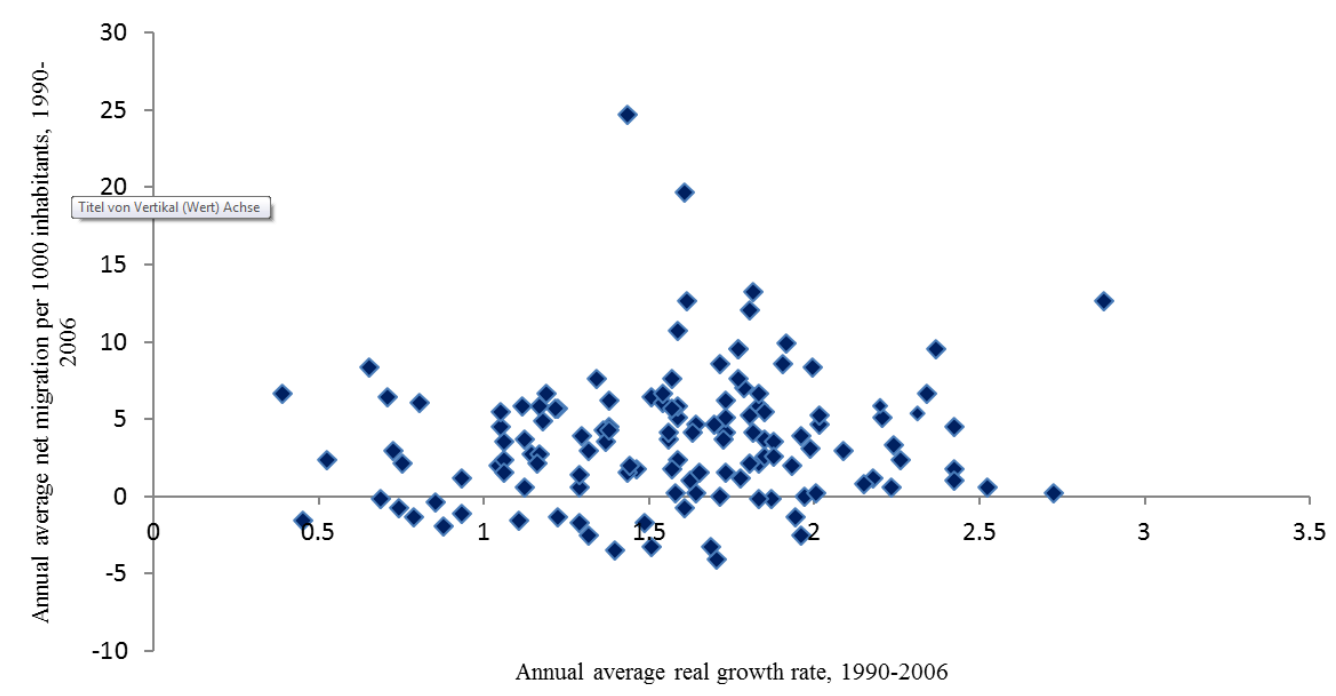

Source: authors' own calculations

Figure 1: EU-15: Regional growth rate and net migration rate, 1990-2006

\section{Empirical Findings}

\subsection{Regional net migration patterns in the EU: graphical analysis}

Before considering other potential determinants of migration, we analyse the relationship of the latter with pecuniary factors. Figure 1 plots the average regional growth rate of each region against the corresponding net migration rate over the period 1990-2006. With the exception of a few outliers, almost all data observations are distributed along an imaginary horizontal band, indicating that on average, differences in regional growth rates across EU regions cannot clearly be associated with significant differences in regional net migration rates alone.

Figure 2 depicts the relationship between regional net migration rates and regional living standards (GDP per capita). The linear trend line seems to indicate the presence of a marginally positive relationship between regional living standards and migration. This relationship however is not significant.

Finally, Figure 3 depicts the relationship between the average net migration rate between 2000 and 2006 and the average net migration rate between 1990 and 1999. The linear trend indicates a strong positive relationship, suggesting a strong persistence of European migration patterns at the regional level. The positive relationship between current and past migration rates remains significant even when we control for other factors. ${ }^{11}$

\subsection{Determinants of net migration across European regions: regression results}

Table 1 reports the regression results when using heteroscedasticity robust system GMM estimations. According to the results, past migration flows are extremely significant in all six model specifications (at a $1 \%$ level of significance) and show a positive, albeit with the passing of time, a declining influence on current net migration. Past migration trends are thus more relevant in the short-run than in the medium-run. This result is in-line with Figure 3 and confirms the presence of a certain path dependency, meaning that current migration flows towards a particular region are determined by migration chain effects and by the migration destination selection of earlier migrants (Massey, Gracia 1987, Shah, Menon 1999). In other words, the higher the number of immigrants in a particular host region, the higher the migration flows towards this particular region. However, network

\footnotetext{
${ }^{11}$ A simple cross-section analysis confirms a significant partial correlation between current (2000-2006) and past migration (1990-1999), which holds after introducing all the considered determinants of migration and country dummies (results upon demand).
} 


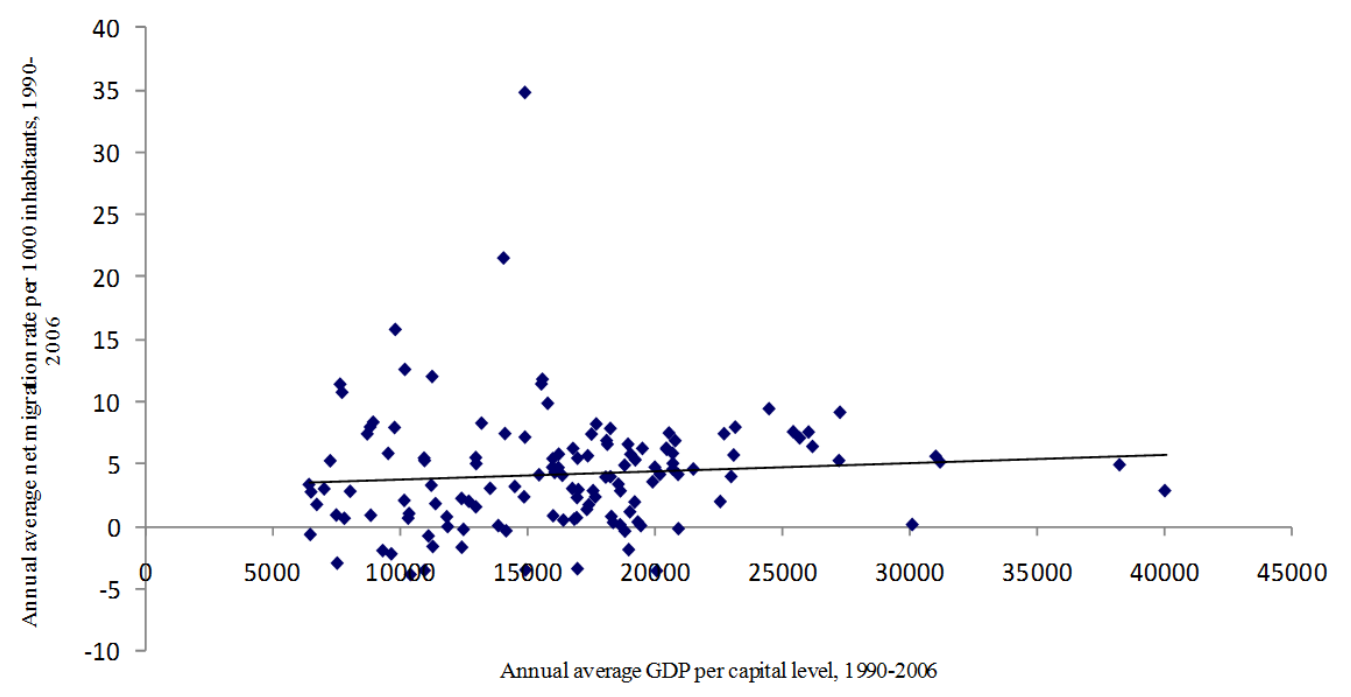

Source: authors' own calculations

Figure 2: EU-15: Regional living standards and net migration rate 1990-2006

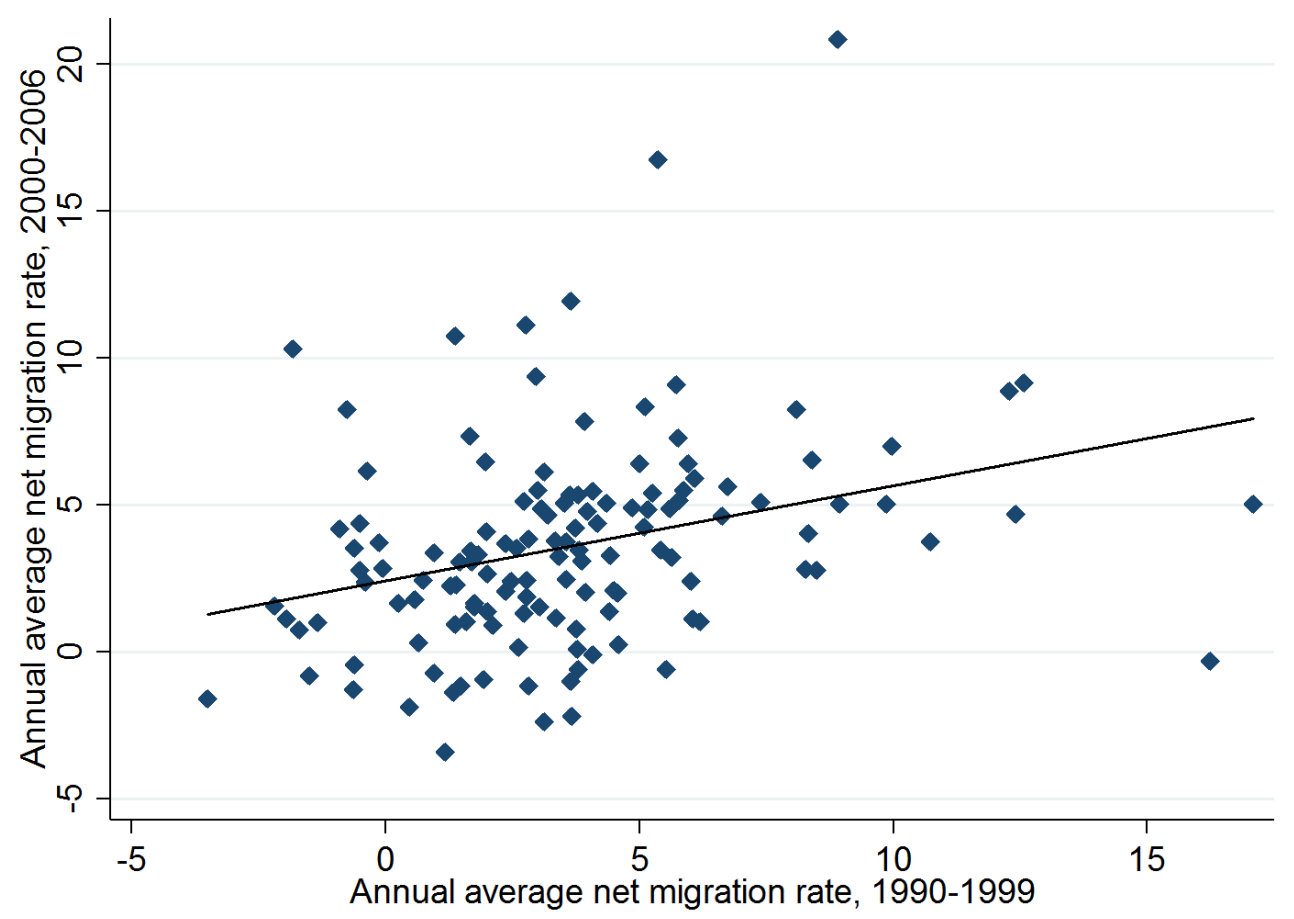

Source: authors' own calculations

Figure 3: EU-15: net migration rate 2000-2006 and net migration 1990-1999 
Table 1: EU-15: Regional net migration in the European Union: Dynamic panel data analysis

\begin{tabular}{|c|c|c|c|c|c|c|}
\hline Regression & $(1)$ & $(2)$ & (3) & $(4)$ & $(5)$ & (6) \\
\hline Time variation & $\mathrm{t}$ & $\mathrm{t}-1$ & $\mathrm{t}-2$ & $\mathrm{t}-3$ & $\mathrm{t}-4$ & $\mathrm{t}-5$ \\
\hline $\begin{array}{l}\text { Lagged net migration } \\
\text { rate }\end{array}$ & $\begin{array}{c}0.774^{* * *} \\
(0.058)\end{array}$ & $\begin{array}{c}0.795^{* * *} \\
(0.053)\end{array}$ & $\begin{array}{c}0.709^{* * *} \\
(0.062)\end{array}$ & $\begin{array}{c}0.645^{* * *} \\
(0.066)\end{array}$ & $\begin{array}{c}0.587^{* * *} \\
(0.069)\end{array}$ & $\begin{array}{c}0.478^{* * *} \\
(0.080)\end{array}$ \\
\hline $\begin{array}{l}\text { Regional unemployment } \\
\text { rate }\end{array}$ & $\begin{array}{l}-0.451^{*} \\
(0.235)\end{array}$ & $\begin{array}{c}-0.392^{* *} \\
(0.188)\end{array}$ & $\begin{array}{l}-0.100 \\
(0.267)\end{array}$ & $\begin{array}{c}0.227 \\
(0.308)\end{array}$ & $\begin{array}{l}0.306 \\
(0.394)\end{array}$ & $\begin{array}{l}0.432 \\
(0.485)\end{array}$ \\
\hline Regional growth rate & $\begin{array}{c}0.114^{* *} \\
(0.048)\end{array}$ & $\begin{array}{l}-0.030 \\
(0.058)\end{array}$ & $\begin{array}{l}-0.018 \\
(0.042)\end{array}$ & $\begin{array}{c}0.041 \\
(0.038)\end{array}$ & $\begin{array}{c}0.055 \\
(0.046)\end{array}$ & $\begin{array}{l}-0.058 \\
(0.06)\end{array}$ \\
\hline $\begin{array}{l}\text { Region's share of young } \\
\text { people }\end{array}$ & $\begin{array}{l}-0.069 \\
(1.231)\end{array}$ & $\begin{array}{c}0.698 \\
(1.185)\end{array}$ & $\begin{array}{c}0.805 \\
(1.953)\end{array}$ & $\begin{array}{l}1.013 \\
(2.609)\end{array}$ & $\begin{array}{l}1.669 \\
(3.269)\end{array}$ & $\begin{array}{l}2.389 \\
(4.057)\end{array}$ \\
\hline National growth rate & $\begin{array}{c}-0.176^{*} \\
(0.091)\end{array}$ & $\begin{array}{c}0.186^{* *} \\
(0.078)\end{array}$ & $\begin{array}{c}0.385^{* * *} \\
(0.076)\end{array}$ & $\begin{array}{c}0.306^{* * *} \\
(0.089)\end{array}$ & $\begin{array}{c}0.356^{* * *} \\
(0.104)\end{array}$ & $\begin{array}{c}0.563^{* * *} \\
(0.095)\end{array}$ \\
\hline Regional wealth & $\begin{array}{c}-0.005^{* * *} \\
(0.002)\end{array}$ & $\begin{array}{l}-0.002 \\
(0.002)\end{array}$ & $\begin{array}{l}-0.002 \\
(0.003)\end{array}$ & $\begin{array}{l}-0.001 \\
(0.004)\end{array}$ & $\begin{array}{l}-0.001 \\
(0.005)\end{array}$ & $\begin{array}{l}-0.002 \\
(0.006)\end{array}$ \\
\hline Regional agglomeration & $\begin{array}{c}0.007 \\
(0.014)\end{array}$ & $\begin{array}{c}0.001 \\
(0.011)\end{array}$ & $\begin{array}{c}0.001 \\
(0.015)\end{array}$ & $\begin{array}{r}-0.002 \\
(0.02)\end{array}$ & $\begin{array}{c}0.001 \\
(0.026)\end{array}$ & $\begin{array}{c}0.001 \\
(0.039)\end{array}$ \\
\hline Social Filter & $\begin{array}{c}0.029^{* *} \\
(0.013)\end{array}$ & $\begin{array}{l}0.016^{*} \\
(0.009)\end{array}$ & $\begin{array}{c}0.035^{* * *} \\
(0.013)\end{array}$ & $\begin{array}{r}0.038^{* *} \\
(0.017)\end{array}$ & $\begin{array}{l}0.041^{*} \\
(0.022)\end{array}$ & $\begin{array}{c}0.046 \\
(0.029)\end{array}$ \\
\hline Social welfare spending & $\begin{array}{c}0.001 \\
(0.003)\end{array}$ & $\begin{array}{l}0.005^{*} \\
(0.003)\end{array}$ & $\begin{array}{c}0.002 \\
(0.002)\end{array}$ & $\begin{array}{l}0.005^{*} \\
(0.003)\end{array}$ & $\begin{array}{c}0.001 \\
(0.003)\end{array}$ & $\begin{array}{c}0.001 \\
(0.002)\end{array}$ \\
\hline Constant & $\begin{array}{l}3.178^{*} \\
(1.459)\end{array}$ & $\begin{array}{l}0.479 \\
(1.45)\end{array}$ & $\begin{array}{l}-0.083 \\
(2.396)\end{array}$ & $\begin{array}{l}-0.434 \\
(3.119)\end{array}$ & $\begin{array}{c}-0.805 \\
(3.829)\end{array}$ & $\begin{array}{l}-1.291 \\
(4.645)\end{array}$ \\
\hline Hansen-J & 0.723 & 0.758 & 0.391 & 0.176 & 0.078 & 0.003 \\
\hline F (p-value) & 0.000 & 0.000 & 0.000 & 0.000 & 0.000 & 0.000 \\
\hline Observations & 1956 & 1925 & 1796 & 1667 & 1538 & 1409 \\
\hline Number of instruments & 146 & 147 & 131 & 116 & 102 & 89 \\
\hline
\end{tabular}

Notes: Standard errors are in parentheses below all coefficients. ${ }^{*},{ }^{* *},{ }^{* * *}$ respectively denote the $10 \%, 5 \%, 1 \%$ significance levels. National wealth and Regional agglomeration have been rescaled by 100 , while the social welfare variable by 1,000 .

effects among migrants seem based on more recent migration flows than those farther in the past, as signalled by the declining coefficient, once time lags are added (see Columns (1) to (6), Table 1 ).

Results show that pecuniary factors tend to have a more nuanced effect on regional migration in Europe than what could have been expected according to dominant migration theories. A region's growth rate only has a significant influence on contemporaneous net migration movements. Once we consider lags, the region's growth rate has no significant effect. Regional economic dynamism - as a proxy for higher earning opportunities - thus seems to have no major impact on individual migration decisions. A region's standard of living, calculated as the regional GDP per capita, seems to have no significant effect in most regressions (only significantly negative in the contemporaneous model - column 1 of Table 1). These results place the proclaimed predominance of potential pecuniary rewards as the main lure for migrants across European regions into perspective. In addition, regional agglomeration - proxied by population density - which under certain circumstances may also serve as a potential alternative indicator of earning opportunities, is shown to have no significant influence on regional net migration. Overall, agglomeration on a regional level does not seem to be an essential driver of regional migration in Europe. ${ }^{12}$

\footnotetext{
${ }^{12}$ See Deas, Hincks (2014) for an analysis of differentials in regional migration patterns in Europe between urban areas and other types of areas, and also between large and small urban areas.
} 
The insignificance or weak significance of the coefficients for pecuniary migration incentives places the focus on other regional aspects, which are likely to be at least as important as monetary perspectives for the attractiveness of European regions towards potential migrants. One of these factors is the regional unemployment rate. Unemployment, as expected, has a significant effect in model specifications (1) and (2), pointing to a negative short-run correlation with the net migration flows. The relevance of unemployment also suggests a cyclical component of migration flows (in line with Huber 2004). Regions where individuals have a lower probability to find a job are on average characterized by a net outflow of people. However, the influence of the unemployment rate diminishes over time, becoming completely irrelevant after specification (2). Any effect of past unemployment rates on current workers' decisions to migrate completely disappears after two years. Hence, a region's unemployment rate is rather important for migration decisions in the very short-run, but wholly irrelevant in the medium- and the long run.

The estimation results in Table 1 further show that the regional ratio of young people relative to other regions has no significant influence on regional net migration movements. The coefficient of the share of young people in a region displays a negative influence on regional net migration, however only up to a lag of two years. Regions with a higher than average share of young people are more likely to experience a migration outflow than regions with an older population structure. Besides lower migration barriers and higher lifetime earning-perspectives of an investment in migration for young movers (Borjas 1989, Zimmermann 2005), the outflow of (young) people may also reflect higher competition among the young for available jobs in regions where the population is relatively young. Faced with high competition for available jobs, young people may therefore be forced to leave their home region in order to find a job somewhere else.

A further interesting result is that the national growth rate is strongly significant over time, showing a positive relationship with the regional net migration rate - with the exception of model specification (1) - indicating that the level of past national economic growth rates is of some relevance for current migration decisions, in line with recent results for European regions (i.e., Sardadvar, Rocha-Akis 2015). This could point to the conclusion that national economic growth rates are a much more visible wage signal than their regional counterparts. Social welfare payments, measured as the ratio of national welfare spending over national GDP multiplied by regional GDP have a very weak positive impact on net migration. However, a significant influence could not be reported for regressions (1), (3), (5) and (6). This could highlight the limited time horizon (around three years) of the influence of past social welfare spending on current migration decisions. Put differently, regions with a well-developed social system tend to attract migrants only in the short-run.

Finally, the social filter index, describing the territorially embedded innovation enhancing character of a region, shows a significant and positive correlation with the regional net migration rate in regressions (1) to (5). This points to the general high importance of (innovation-enhancing) social conditions in order to attract migrants. Hence, territorially embedded characteristics, such as the existence of a favourable educational environment and the associated opportunities for migrants to increase their own productivity through interaction with each other (Rudd 2000, Acemoglu, Angrist 2001, Di Addario, Patacchini 2008) seem crucial in the potential of any European region to attract migrants.

Decomposing the social filter into its individual components yields interesting results. First, among the factors that compose the social filter index, educational variables are highly important. The level of education of the employed labour force has a strong positive influence (0.7174) on the filter index. The presence of a high-tech or high-skilled labour force tends to attract people, once all other factors are controlled for. These findings support - to some extent - the hypothesis that highly educated people are more likely to move to areas with an already highly skilled labour force and with industries requiring highly skilled labour. People eligible to work in such industries will find (better paid) jobs and are therefore more likely to migrate. The educational level of the total regional population also has a positive influence (although not as strong (0.0514)). The slight positive impact of the latter variable may signal a positive influence of a good regional educational system on net migration movements. Second, the composition of 
productive resources in a region, proxied by the relative number of people employed in agriculture has a negative influence in the framework of the social filter (-0.6948) and impacts net migration negatively. Regions with a more backward sectoral composition (high percentage of workers in the agricultural sector) therefore tend to lose people. ${ }^{13}$

\subsection{Robustness}

A number of statistical robustness tests have been performed in order to assess the robustness of the dynamic migration models. Some of them are reported below the respective regression results at the bottom of Table 1 and referred to in this section. The F-test of joint insignificance of the explanatory variables is in all cases strongly rejected at a $1 \%$ level. The Hansen-J statistic reported in Table 1 is only significant for the last two regressions (using a four and five year lag structure), reflecting the general validity of the instrument set in most specifications. ${ }^{14}$ Regarding potential multicollinearity issues, Variance Inflation Factor (V.I.F) tests have been performed on pooled-data versions of the different model specifications. Given that our model is based on panel-data estimations with non-negligible individual fixed effects, the V.I.F test based on pooled regressions can only deliver limited results. The results of the V.I.F. tests (available upon request) reflect no concern for multicollinearity.

In an additional exercise we consider a static specification similar to that in equation (1), but excluding past migration. This static version follows a heteroscedasticity-consistent cluster-specific fixed effects model (FEM). The results are reported in Table A.2 in the appendix. These findings are qualitatively similar to those obtained in our dynamic specification, and support the relevance of region-specific characteristics beyond pecuniary factors in explaining net migration flows across European regions: our social filter is strongly significant in five out of the six estimations. Social welfare spending is also significant in four out of the six estimations. The main difference with our dynamic specification in Table 1 is that without controlling for past migration, the regional economic wealth becomes statistically significant in most specifications.

\section{Conclusions}

The main purpose of this paper has been to assess the role of pecuniary factors in comparison to other alternatives as a major driver for migration. Given the substantial growth and income disparities across the EU's regions, we examined the question of whether total regional migration in the EU follows money and contrasted these findings against other potential migration drivers. The impact of money and other relevant factors on migration has been analysed by means of a dynamic migration model covering 133 European regions and a time horizon of 17 years. The presented results tend to cast doubt on the relevance of traditional migration theory for recent regional migration trends in Europe. The results give little support to the idea of migration following regional wealth or economic dynamism. It is therefore hardly possible to claim that migration across EU's regions mainly follows the money, in contradiction with most traditional migration theories where money is reported to play an essential role in shaping individual migration decisions. The findings may however, also point to the fact that substantial migration barriers still exist in the EU, which may result in a likely reduction of possible monetary rewards to migration.

The findings suggest that other factors, such as the likelihood of finding a job, past migration trends and the presence of migrants from a similar origin, social security related

\footnotetext{
${ }^{13}$ In order to get an idea of whether significant differences regarding inter-regional migration patterns exist among European Member States, we run additional regressions for selected EU Member States. The results are reported in Table A.3 in the appendix and reveal important differences across EU countries in the factors that determine migration patterns. While in some countries pecuniary migration incentives seem to exert some influence on inter-regional net migration, this is not the case in all of the others. Unemployment and youth generally play a more important role in almost all Member States analysed.

${ }^{14} \mathrm{~A}$ small caveat of the regression results reported in Table 1 is the large number of instruments (especially in the first two regressions with 1 and 2 lags respectively) compared to the number of individuals (133). According to Roodman (2006), too many instruments can lead to an over fit of the endogenous variables (Roodman 2006, 40).
} 
aspects, or the availability of a good educational system, and further human capital related regional characteristics are decisive elements for migration flows at the EU regional level. The influence of these factors also varies according to the time frame considered. Whereas some - mainly unemployment, past migration trends, and social welfare spending - operate fundamentally in the short-run, others, such as the presence of an adequate social filter, have an association with net migration trends which is longer lasting. In addition, the significant positive results of the social filter index reinforce the view that it may be easier for high skilled rather than for low-skilled workers to find jobs in other regions and thus, to move. This may also hide the fact that highly educated people are much more sensitive to inter-regional wage and employment differentials. This paper set out to reveal some new insight on migration determining factors on an EU-wide regional level. It may however, also be understood as a call for further research in order to develop policy recommendations concerning inter-regional mobility in the EU and beyond. Further studies could be conducted by means of gravity models in order to directly link sending and receiving regions. In addition, it would also be interesting to see how migration movements are influenced by the size of regional manufacturing and services sectors, as well as to explicitly investigate the role of human capital and education on EU-wide regional net migration rates.

\section{References}

Acemoglu D, Angrist J (2001) How large are human capital externalities? Evidence from compulsory schooling laws. NBER Macroeconomics Annual 15: 9-59. CrossRef.

Assadian A (1995) Fiscal determinants of migration to a fast-growing state: How the aged differ from the general population. Review of Regional Studies 25: 301-15

Bauer T, Zimmermann KF (1997) Network migration of ethnic Germans. International Migration Review 31: 143-149. CrossRef.

Borjas G (1989) Economic theory and international migration. International Migration Review 23: 457-485. CrossRef.

Borjas GJ, Bronars SG, Trejo SJ (1992) Self-selection and internal migration in the United States. Journal of Urban Economics 32: 159-185. CrossRef.

Burda M, Wyplosz C (1992) Human capital, investment and migration in an integrated Europe. European Economic Review 36: 677-684. CrossRef.

Cairns D, Menz S (2007) Youth on the move? Exploring youth migrations in Eastern Germany and Northern Ireland. In: Geisen T, Riegel C (eds), Jugend, Partizipation und Migration. Orientierungen im Kontext von Integration und Ausgrenzung. Springer Publishing, Wiesbaden, 325-339. CrossRef.

Caselli C, Coleman J (2001) The U.S. structural transformation and regional convergence: A reinterpretation. Journal of Political Economy 109: 584-616. CrossRef.

Castells-Quintana D, Ramos R, Royuela V (2015) Income inequality in European regions: Recent trends and determinants. Review of Regional Research 35: 123-146. CrossRef.

Cheshire PC, Magrini S (2006) Population growth in European cities: weather matters but only nationally. Regional Studies 40: 23-37. CrossRef.

Crescenzi R, Rodríguez-Pose A (2008) Infrastructure endowment and investment as determinants of regional growth in the European Union. European Investment Bank Papers 13: 62-101 
Day MK (1992) Interprovincial migration and local public goods. Canadian Journal of Economics / Revue Canadienne d'Economie 25: 123-144

Décressin J, Fatàs A (1995) Regional labour market dynamics in Europe. European Economic Review 39: 1627-1655. CrossRef.

Décressin JW (1994) Internal migration in West Germany and implications for East-West salary convergence. Review of World Economics 130: 231-257

Deas I, Hincks S (2014) Migration, mobility and the role of European cities and regions in redistributing population. European Planning Studies 12: 2561-2583. CrossRef.

Di Addario S, Patacchini E (2008) Wages and the city: Evidence from Italy. Labour Economics 15: 1040-1061. CrossRef.

Fatàs A (2000) Intranational labor migration, business cycles and growth. In: Hess G, van Wincoop E (eds), Intranational Macro-Economics. Cambridge University Press, Cambridge, $156-188$

Ferguson M, Ali K, Olfert MR, M P (2007) Voting with their feet: Jobs versus amenities. Growth and Change 38: 77-110. CrossRef.

Fields GS (1975) Rural - urban migration, urban unemployment and job search activities in LDCs. Journal of Development Economics Theory and Evidence 2: 165-187. CrossRef.

Fields GS (1979) Place-to-place migration: Some new evidence. The Review of Economics and Statistics 61: 21-32. CrossRef.

Florida R (2002) The Rise of the Creative Class. Basic Books, New York

Ghatak S, Levine P, Price SW (1996) Migration theories and evidence: An assessment. Journal of Economic Surveys 10: 159-98. CrossRef.

Greenwood MJ (1975) Research on internal migration in the United States: A survey. Journal of Economic Literature 13: 397-433

Greenwood MJ (1985) Human migration: Theory, models and empirical studies. Journal of Regional Science 25: 521-544. CrossRef.

Greenwood MJ (1997) Internal migration in developed countries. In: Rosenzweig M, Stark O (eds), Handbook of Population and Family Economics. Elsevier, Amsterdam. CrossRef.

Haapanen M (2000) Impact of expected earnings on interregional migration decisions in Finland. ERSA conference papers, European Regional Science Association

Haapanen M, Ritsilä J (2007) Can migration decisions be affected by income policy interventions? Evidence from Finland. Regional Studies 41: 339-348. CrossRef.

Harris JR, Todaro MP (1970) Migration, unemployment and development: A two sector analysis. American Economic Review 60: 126-142

Hicks J (1932) The Theory of Wages. McMillan, London

Hooghe M, Trappers A, Meuleman B, Reeskens T (2008) Migration to European countries. A structural explanation of patterns, 1980-2004. International Migration Review 42: 476-504. CrossRef.

Huber P (2004) Inter-regional mobility in Europe: A note on the cross - country evidence. Applied Economics Letters 11: 619-624. CrossRef.

Jennissen R (2003) Economic determinants of net international migration in Western Europe. European Journal of Population / Revue Européenne de Démographie 19: $171-198$ 
Katz E, Stark O (1988) Individual migration as a family strategy: Young women in the Philippines. Population Studies 42: 473-486. CrossRef.

Lee ES (1972) Eine Theorie der Wanderung. In: Széll G (ed), Regionale Mobilität. München, 115-129

Lundborg P (1991) Determinants of migration in the Nordic labor market. Scandinavian Journal of Economics 93: 363-375. CrossRef.

Lundvall BA (1992) National systems of innovation: Towards a theory of innovation and interactive learning. Pinter, London

Malecki E (1997) Technology and economic development: The dynamics of local, regional and national competitiveness ( $2^{\text {nd }}$ ed.). Addison Wesley Longman, London

Massey DS, Arango J, Hugo G, Kouaouci A, Pellegrino A, Taylor JE (1993) Theories of international migration: A review and appraisal. Population and Development Review 19: 431-466. CrossRef.

Massey DS, Arango J, Hugo G, Kouaouci A, Pellegrino A, Taylor JE (1998) Worlds in Motion. Understanding International Migration at the end of the Millenium. Oxford University Press

Massey DS, Gracia EF (1987) The social process of international migration. Science 237: 733-738. CrossRef.

Mincer J (1978) Family migration decisions. Journal of Political Economy 86: 749-773. CrossRef.

Öberg S (1997) Theories on inter-regional migration: An overview. In: Blotevogel HH, Fielding AJ (eds), People, jobs and mobility in the new Europe. Wiley, Chichester, 3-22

Ottaviano G, Puga D (1998) Agglomeration in the global economy: A survey of the 'new economic geography'. World Economy 21: 707-731. CrossRef.

Partridge MD (2010) The duelling models: NEG vs amenity migration in explaining US engines of growth. Papers in Regional Science 89: 513-537. CrossRef.

Partridge MS, Rickman DS, Olfert MR, Ali K (2012) Dwindling US internal migration: Evidence of spatial equilibrium or structural shifts in local labor markets? Regional Science and Urban Economics 42: 375-388. CrossRef.

Pekkala S (2002) Migration and individual earnings in Finland: A regional perspective. Regional Studies 36: 13-24. CrossRef.

Pekkala S (2003) Migration and individual earnings in Finland: Regional differences in migration determinants and migrant types. International Regional Science Review 26: 446-482. CrossRef.

Piore MJ (1979) Birds of Passage: Migrant Labour in Industrial Societies. Cambridge University Press, Cambridge

Pissarides C, McMaster I (1990) Regional migration, wages and unemployment: Empirical evidence and implications for policy. Oxford Economic Papers 42: 812-831

Puga D (2002) European regional policies in the light of recent location theories. Journal of Economic Geography 2: 373-406. CrossRef.

Puhani PA (2001) Labour mobility: An adjustment mechanism in Euroland? Empirical evidence for Western Germany, France and Italy. German Economic Review 2: 127-140. CrossRef.

Ranis G, Fei JCH (1961) A theory of economic development. American Economic Review 51: 553-565 
Rodríguez-Pose A (1999) Innovation prone and innovation averse societies, economic performance in Europe. Growth and Change 30: 75-105. CrossRef.

Rodríguez-Pose A, Crescenzi R (2008) R\&D spillovers, innovation system and the genesis of regional growth in Europe. Regional Studies 42: 51-67

Rodríguez-Pose A, Ketterer TD (2012) Do local amenities affect the appeal of regions in Europe for migrants? Journal of Regional Science 52: 535-561. CrossRef.

Rodríguez-Pose A, Tselios V (2010) Returns to migration and educational externalities in the European Union. Papers in Regional Science 89: 411-434. CrossRef.

Rodríguez-Pose A, Tselios V (2012) Individual earnings and educational externalities in the European Union. Regional Studies 46: 39-57. CrossRef.

Rodríguez-Pose A, Vilalta-Bufí M (2005) Education, migration, and job satisfaction: The regional returns of human capital in the EU. Journal of Economic Geography 5: 545-566. CrossRef.

Roodman D (2006) How to do xtabond2: An introduction to 'difference' and 'system' GMM in Stata. Centre for Global Development, Working Paper No. 103

Rudd J (2000) Empirical evidence on human capital spillovers. Finance and Economics Discussion Series 2000-46. Board of Governors of the Federal Reserve System (U.S.).

Sardadvar S, Rocha-Akis S (2015) Interregional migration within the European Union in the aftermath of the Eastern enlargements: A spatial approach. Review of Regional Research. CrossRef.

Schmidt CM, Stilz A, Zimmermann KF (1994) Mass migration, unions and government intervention. Journal of Public Economics 55: 185-201. CrossRef.

Shah NM, Menon I (1999) Chain migration through the social network: Experience of labour migrants in Kuwait. International Migration 37: 361-382. CrossRef.

Sjaastad LA (1962) The costs and returns of human migration. Journal of Political Economy 70: 80-93. CrossRef.

Stark O (1991) The Migration of Labor. Blackwell Publishers, Cambridge, MA

Surico P (2003) Geographic concentration and increasing returns. Journal of Economic Surveys 17: 693-708. CrossRef.

Tassinopoulos A, Kristensen HWS (1998) Mobility and migration of labour in the European Union and their specific implications for young people. CEDEFOP - European Centre for the Development of Vocational Training, $1^{\text {st }}$ ed., Thessaloniki

Todaro MP (1969) A model of labour migration and urban unemployment in less-developed countries. American Economic Review 59: 138-48

Zimmermann KF (2005) European labour mobility: Challenges and potentials. De Economist 153: 425-450. CrossRef. 
A Appendix

Table A.1: Data sources and exact definition of the variables

\begin{tabular}{|c|c|c|}
\hline Variable & Exact definition & Source \\
\hline \multicolumn{3}{|c|}{ Dependent variable } \\
\hline Net migration rate & $\begin{array}{l}\text { Net migration standardised by the region's } \\
\text { population (per } 1000 \text { inhabitants) }\end{array}$ & $\begin{array}{l}\text { Eurostat }+ \text { authors' own } \\
\text { calculations }\end{array}$ \\
\hline \multicolumn{3}{|c|}{ Explanatory variables } \\
\hline $\begin{array}{l}\text { Annual regional growth } \\
\text { rate }\end{array}$ & $\begin{array}{l}\text { Growth rate of GDP PPS per inhabitant } \\
\text { standardised by the average annual growth } \\
\text { rate of all regions }\end{array}$ & $\begin{array}{l}\text { Eurostat }+ \text { authors' own } \\
\text { calculations }\end{array}$ \\
\hline $\begin{array}{l}\text { Level of a region's } \\
\text { standard of living }\end{array}$ & Regional GDP PPS per inhabitant & Eurostat \\
\hline $\begin{array}{l}\text { National social welfare } \\
\text { expenditure }\end{array}$ & $\begin{array}{l}\text { National social expenditure/cap. over } \\
\text { national GDP/cap. multiplied by regional } \\
\text { GDP/cap. (all in PPS) }\end{array}$ & $\begin{array}{l}\text { Eurostat }+ \text { authors' own } \\
\text { calculations }\end{array}$ \\
\hline $\begin{array}{l}\text { Regional unemployment } \\
\text { rate }\end{array}$ & $\begin{array}{l}\text { Regional unemployment rate standardised } \\
\text { by the average annual unemployment rate } \\
\text { of all regions }\end{array}$ & $\begin{array}{l}\text { Eurostat }+ \text { authors' own } \\
\text { calculations }\end{array}$ \\
\hline Regional agglomeration & Population density & Eurostat \\
\hline $\begin{array}{l}\text { Region's share of young } \\
\text { people }\end{array}$ & $\begin{array}{l}\text { People aged } 15-24 \text { years as } \% \text { of total } \\
\text { population and measured as the deviation } \\
\text { from the annual mean value of all regions }\end{array}$ & $\begin{array}{l}\text { Eurostat }+ \text { authors' own } \\
\text { calculations }\end{array}$ \\
\hline National growth rate & $\begin{array}{l}\text { Growth rate of national GDP per } \\
\text { inhabitant }\end{array}$ & $\begin{array}{l}\text { Eurostat }+ \text { authors' own } \\
\text { calculations }\end{array}$ \\
\hline \multicolumn{3}{|c|}{ Social Filter } \\
\hline Agriculture employment & $\%$ of total employment & Eurostat \\
\hline $\begin{array}{l}\text { Employed people with } \\
\text { tertiary education }\end{array}$ & $\%$ of total employment & $\begin{array}{l}\text { Eurostat }+ \text { authors' own } \\
\text { calculations }\end{array}$ \\
\hline $\begin{array}{l}\text { Population with } \\
\text { tertiary education }\end{array}$ & $\%$ of population & $\begin{array}{l}\text { Eurostat }+ \text { authors' own } \\
\text { calculations }\end{array}$ \\
\hline
\end{tabular}




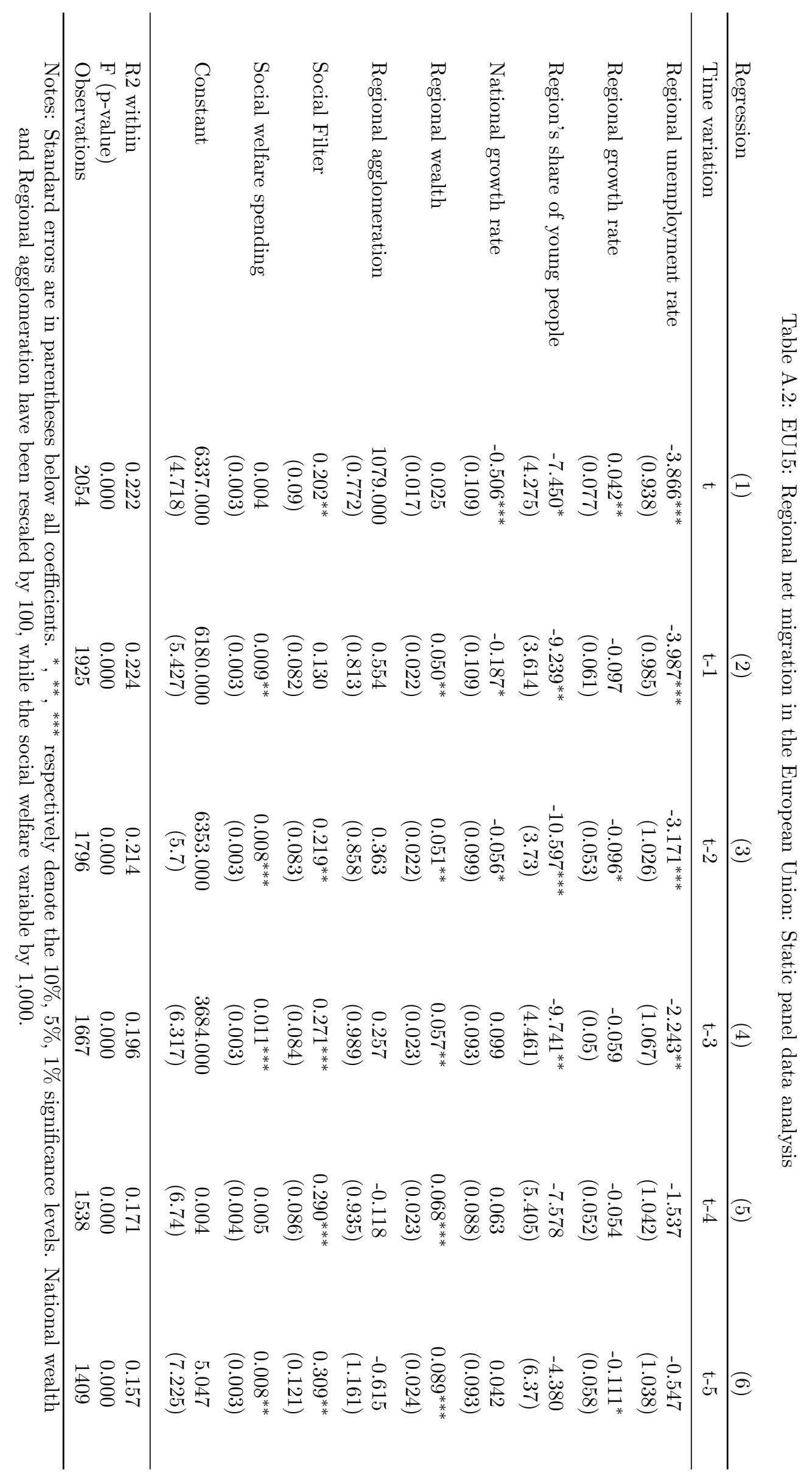




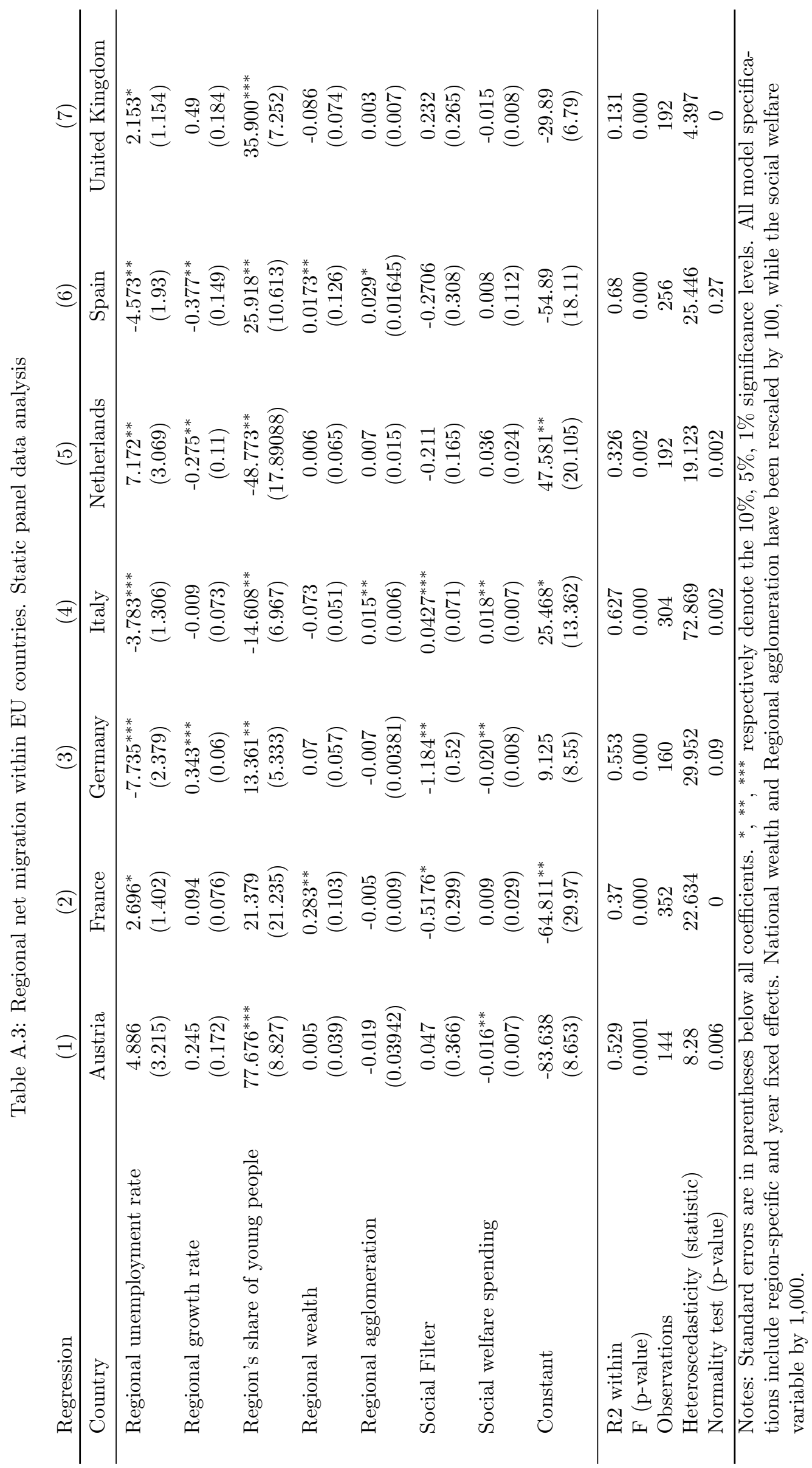

